Tér és Társadalom 23. évf. 2009/1. 19-42. p.

\title{
A KÖZLEKEDÉS SZEREPE A POLICENTRIKUS VÁROSHÁLÓZAT FEJLESZTÉSÉBEN ${ }^{1}$
}

\author{
(The Role of the Transportation \\ in the Development of a Polycentric Urban Network)
}

\author{
FLEISCHER TAMÁS
}

Kulcsszavak:

policentrikus városhálózat hálózatok közlekedés hierarchikus kapcsolatok alkalmazkodóképesség elérhetỏség biztonság

A tanulmány policentrikus városhálózaton sürün elhelyezkedö, de nem összenött városi településeket éri, amelyek között erös kölcsönös kapcsolatok (horizontális együttmüködések) alakulnak ki, miközben nincsenek egymással klasszikus hierarchikus viszonyban, és kapcsolatuk alapja a specializálódás. A policentrikus városhálózat fejlesztésének az eredményességét nem az minösiti, hogy egyes városokat mennyire sikerül fejleszteni, hanem az, hogy a (városokat is magában foglaló) térség egésze számára mit képes a struktüra nyújtani. A térségen belül válasziási lehetöséget kináló sokoldalú kapcsolati hálók kẻpesek a térség számára a policentrikus struktúrát tartósitani és a korábbi monocentrikus felépitéshez képest a változásokhoz való alkalmazkodás, az adaptivitás és a sokirányu együttmüködés feltételeit biztositani. $E$ policentrikus hálózati séma a minimális kényszerkapcsolatokhoz képest alternativ, redundáns elérési lehetőségeket is lehetỏvé tesz, tehát látszólag 'pazarló' az egy adott feladat végrehajtására optimalizált hierarchiához képest. Fontos azonban megérteni, hogy a policentrikus városhálózatra nem azért van szükség, mert ez tudná a leghatékonyabban kiszolgálni az ellátási modellt, hanem azért, mert a belsö eröforrások hasznositásához, a térségi endogén fejlödés elömozditásához, a változó körülményekhez történó alkalmazkodás képességéhez a térségben lévö települések sokoldalú kapcsolatrendszerére van szükség, és ennek a fejlödésnek a bázisa a policentrikus városhálózat. Hosszú távra tervezett létesitményeinknek olyan körülmények között kell helytállniuk, amelyeket ma nem tudunk elöre meghatározni, és amely körülményeket ráadásul folyamatos változás fog jellemezni. Az adaptivitás képességének felértékelödésével a térségi belsö kapcsolatrendszer kiterjedtsége és erössége maga is eröforrássá, versenyképességi tényezövé válik. A feladat nem egyszerüen az, hogy a közlekedést hozzáigazitsuk a policentrikus városhálózat tervezett elképzeléseihez, hanem a két kérdéskörnek van egy közös meta-szintje; ez pedig a fenntartható, méltányos és hosszú távon versenyképes térség formálása.

\section{Bevezetés}

A ,policentrikus városfejlesztési koncepció” kifejezés tulajdonképpen vonatkozhat a többcentrumú városszövet fejlesztésére is (amivel jelen keretek között nem szándékozunk foglalkozni), továbbá a policentrikus városhálózat fejlesztésére irányuló koncepcióra. A nemzetközi irodalomban ez utóbbi fogalomra a 'policentrikus város régió' (Polycentric Urban Region - PUR) kifejezés honosodott meg - bár, mint látni fogjuk, ez utóbbin is különböző szerzők esetenként mást és mást értenek. 
Fleischer Tamás : A közlekedés szerepe a policentrikus városhálózat fejlesztésében.

Tér és Társadalom 23. évf. 2009/1. 19-42. p.

$20 \quad$ Fleischer Tamás

TÉT XXIII. évf. 2009

$\mathrm{Az}$ alábbi írás éppen az értelmezés eltéréseire való tekintettel mindenekelött rögzíteni kívánja, hogy milyen tartalommal használjuk ebben a tanulmányban a policentrikus városhálózat kifejezést, milyen településhálózati, településpolitikai célok szolgálatában válik ma Magyarországon időszerủvé az elösegitése - és ebben a kontextusban térünk rá a tanulmány tulajdonképpeni mondanivalójának a tárgyalására, azaz a policentrikus városhálózat fejlődését elösegitó, azzal összhangban lévő közlekedéshálózat és közlekedés követelményeinek a leírására.

\section{A (közlekedési) hálózatokkal kapcsolatos megalapozó összefüggések áttekintése}

\section{A policentrikus településhálózat értelmezéséröl (térségi funkciók megosztása egy adott településcsoporton belül)}

A policentrikus város-hálózat (PUR, Polycentric Urban Region) népszerúségének új hulláma indult el a kilencvenes évek végén a tudományos megközelítésben. Több neves szakmai folyóirat is (European Planning Studies 1998; Urban Studies 2001) különszámot szentelt a kérdéskörnek. Parr (2003) megállapítja, hogy három kérdésben konszenzus alakult ki a PUR támogatói között, nevezetesen, hogy 1) a PUR egy megkülönböztetésre érdemes regionális formáció, hogy 2) potenciálisan magasabb gazdasági teljesítmény elérését ígérheti, és hogy ezért 3) egy olyan kívánatos keret, aminek a létrejöttét szakpolitikai eszközökkel is érdemes ösztönözni.

Miközben a konszenzusba beleértett 2) és 3) pontok is részben bizonyításra várnak, egyáltalán nem ugyanilyen mértékben tekinthető elfogadottnak az, hogy mit is jelent pontosan a PUR. Parr (2003) hét pontban foglalja össze, mit érdemes szerinte policentrikus város régión érteni. Az első négy pont tartalma tulajdonképpen összefoglalható annyiban, hogy súrü, de nem összenőtt városhálózatról van szó, a további három kritérium teszi hozzá a specifikus elvárásokat.

1) Egymástól elkülönült városok alkotják (amelyek különféle mintázatot alkothatnak, így elhelyezkedhetnek egy folyosó mentén, halmazban vagy máshogy).

2) Van tehát egy minimális elkülönültség a városok között, azaz a folyamatos metropolisz-szövet (multi-centered metropolitan area) nem értendő ide.

3) Létezik az elkülönültségre egy felső limit is, célszerúen az egymástól kb. egy órản belül megközelíthetó települések alkothatnak egy PUR-t.

4) A központok egymástól való távolsága kisebb, mint az összehasonlításra figyelembe vehetö, nem PUR térségek településhálózatán.

5) A PUR-t alkotó centrumok nincsenek egymással klasszikus hierarchikus viszonyban.

6) Erös és kölcsönös belsố kapcsolatrendszer van a központok között, gazdasági, kereskedelmi, átfedő munkaerő-piaci stb. 
Fleischer Tamás : A közlekedés szerepe a policentrikus városhálózat fejlesztésében.

Tér és Társadalom 23. évf. 2009/1. 19-42. p.

7) Az egyes centrumok specializálódnak, sajátos profiljuk alakul ki az együttmúködésben, amit külsö kapcsolatokban is képviselnek.

E tulajdonságokból következik, hogy a PUR-t érdemes megkülönböztetni más regionális formációktól. A PUR:

- nem azonos a folytonos városi szövetet alkotó többpólusú metropolisz térséggel (akkor sem, ha történetileg ez utóbbiak gyakran egymáshoz közeli korábbi települések összenövésével jöttek létre),

- nem azonos a belsỏ struktúra nélküli (pl. központhiányos) homogén térséggel,

- nem azonos a 'központi hely' elvre alapozott centralizált régióval, amit a központ dominanciảja, a hierarchia és a dominánsan e hierarchia mentén alakuló kapcsolatok jellemeznek,

- nem azonos a központ szerepét ugyancsak kiemelö városrégióval sem - sőt,

- nem azonos utóbbinak esetenként előforduló iker-központos változatával sem.

Parr (2003) a policentrikus várostérségek kialakulásának három tipikus esetét is felsorolja. Ilyen az egymáshoz közeli városi központok erősödö egyuittmüködése kereskedelmi, technológiai, ipari stb. kapcsolatok elmélyülésével. Egy másik eset a hagyományos mezőgazdasági térségekben kialakuló kézmûves és helyi feldolgozóiparra alapozódó együttmüködés a települések között, és egy harmadik forma a közös természeti kincsre (gyakran bányászatra) ráépült ipari tevékenységek kapcsolatba szervezödése, közeli települések között kialakuló munkamegosztása. Nyilvánvaló, hogy ezekben az alapesetekben hasonló kultúrájú, de mégis egymást kiegészítö tevékenységek idézik elö a kapcsolatok létrejöttén keresztül a policentrumok kialakulását. Ugyanakkor Parr felhívja a figyelmet a fordított viszony jelentőségére is, azaz a már létrejött struktúra és térségi kapcsolatrendszer olyan esetekben is attraktív maradhat, ha az eredeti iparág kifulladt; és ilyenkor éppen forditva, a létezö kapcsolatrendszer és együttmüködés segitheti hozzá a térséget ahhoz, hogy ủj profil telepedjen meg a korábbi helyén.

\section{A policentrikus városhálózat kialakitásának eltéró értelmezései}

Az eddigi szempontokat végiggondolva nyitott kérdésként jelenik meg, vajon milyen mértékben és milyen időtávlatban lehet hazai koncepciókészités esetében általános modellnek tekinteni a fenti értelemben vett policentrikus városhálózat célkitüzését, illetve az mennyiben inkább bizonyos elözetes körülmények fennállása esetén, egyes területeken fejleszthetö modell. Faragó a modellt általános érvényü normatív elvárásként fogalmazza meg, amikor az Új Magyarország Fejlesztési Terv (NFT II, NSRK) kritikájaként említi, hogy abban a policentrikus városfejlesztés nem alkot explicit és következetes fejlesztési irányt (Faragó 2006, 98).

Jelenleg ezt a jelzett dilemmát a hazai tervezés felemás módon inkább elfedi, mintsem megoldja; nevezetesen a policentrikus városhálózat elképzelésébe rendre belekeveredik a hierarchikus, dekoncentrált (de továbbra is monocentrikus) városhálózat közbenső szintjei fejlesztésének a célkitüzése. Ilyennek tekinthető a térségi feladatok 
Fleischer Tamás : A közlekedés szerepe a policentrikus városhálózat fejlesztésében.

Tér és Társadalom 23. évf. 2009/1. 19-42. p.

elosztásának minden olyan megközelítése, amely a funkcióknak kizárólag a vertikális megosztására törekszik, és mellözi a horizontális munkamegosztás lehetöségeit.

Faragó (2006) mind a nemzetközi alapokat, mind a hazai gyakorlatot áttekintő nagyívü cikkében is benne maradt ez a kettősség, amennyiben a szerző alapelvi javaslataiban (Faragó 2006,100) a policentrikus területfejlesztés címén több pólus fejlesztését szorgalmazza, de eközben mégsem szabadul meg attól, hogy összességében a pólusokkal is a monocentrikus térszervezödést építse tovább. Pedig más helyen (Faragó 2006, 88) éppen Christaller modelljének utóélete kapcsán a cikk árnyaltan kifejti, hogy ma már nem a városok (pólusok) statikus hierarchiááában kell az öszszefüggéseket értelmeznünk, hanem egymást átlapoló hálózati szintek hierarchiájáról van inkább szó, amely szintek maguk „horizontálisan” többpólusúak.

Kicsit elöre ugorva a közlekedési hálózatokhoz, pontosan ennek az elvnek feleltethetỏ meg a közlekedési hálózatok hierarchiája is, amikor (pl. Fleischer 1994) az egyes hálózati rétegeket nem a felsőbb szint betápláló ágaiként, egyetlen fastruktúraként kívánjuk kezelni, hanem a teret külön-külön is lefedö, ott eltérő funkciókat ellátó hálózati szintekként. Nevezetesen a közúthálózat esetében faluközi kapcsolatokat szolgáló alsóbbrendú úthálózatot, városokat összekapcsoló fơhálózatot, és régiókat összekötő gyorsforgalmi hálózatot különböztet meg az idézett cikk, mint a saját jelzett funkciójának betöltésére külön-külön is alkalmas szinteket.

A policentrikus mintázatnak éppen az biztosithatja az általános érvényú modellként való figyelembevehetöségét, ha hangsúlyt adunk és teret biztositunk az egyes szinteken belüli, horizontális együttmüködéseknek. A hierarchikus kapcsolatrendszer fa-struktúrája ugyanis kizárólag a különbözö szintek között létesít összeköttetést. Az egyes szinteken belüli munkamegosztás, együttmüködés, helyettesítés stb. lehetősége és fontossága ettől alapvetően eltérő gondolat, és a többpólusúságnak a lényegét jelenti. Amíg csak a településhierarchián lévö közbensö szintek szerepének a felértékelödéséröl beszélünk, addig egy monocentrikus, dekoncentrált szerkezeten „fel-le" tologatjuk a hatásköröket, ami nyilván nem közömbös az egyes érintettek számára, de nem jelent alapvetó strukturális változást. A szubcentrumok súlyának változása tehát fontos kérdés ugyan, de amíg mindez továbbra is vertikális kapcsolatokon nyugszik, addig a szubcentrumok szubcentrumok maradnak, a fejlesztés nem jelent policentrikus mintázatot, és nem ad biztositékot az arányok tartós megváltozására és az egyes centrumok/szintek endogén fejlödésére. Ennek az összefüggésnek a megértését tekintjük a policentrikus fejlesztés lényegének, és értelemszerüen ennek az elvnek a közlekedéssel való támogatását tekintjük a tanulmány fö kérdésének.

\section{A hálózatépitési elvek és a különbözö struktúrájú hálózatok hatásai}

A közlekedési hálózatokra vonatkozó megalapozó „hálózatológiai” ismereteket részletesen összegyủjtöttük és kifejtettük egy korábbi tanulmányunkban (Fleischer 2006). Itt ezért csak rövid áttekintésre és a jelenlegi témához kapcsolódó megjegyzésekre szorítkozunk. 
Fleischer Tamás : A közlekedés szerepe a policentrikus városhálózat fejlesztésében.

Tér és Társadalom 23. évf. 2009/1. 19-42. p.

TÉT XXIII. évf. 2009 — 1

A közlekedés szerepe a ...

23

A hálózatok hatásait elemezve a fentebb tárgyalt (azaz alsóbbrendú, főhálózati és interregionális) hierarchikus hálózati szinteken túlmenően Provan és Milward (2001) munkájára támaszkodva van egy másik kategóriarendszer is, ami szerint célszerü megkülönböztetni egymástól a hálózatok legalább három, minöségében eltérỏ hatásösszetevőjét.

Az első csoportot a csomópontok világa alkotja, vagyis azok az elemi pontok, amelyeket a hálózat összeköt. Ezeknek a pontoknak csak egyik, specifikus tulajdonsága, hogy részét alkotja a hálózatnak, a pontok ezen kívül is funkcióval, sajátos tulajdonságokkal rendelkeznek, a valóságban kiterjedésük is van - esetünkben települések (más hálózatoknál lehetnének pl. vállalati egységek, intézmények stb.). A hálózathoz képest azonban elemi egységekről van szó, amelyek releváns jellemzői általában skalár jellegủ mutatókkal kifejezhetők (méret, lakosszám stb.).

A második csoportot maga a hálózat képezi, melynek a csomópontok mellett az élek képezik a részét. Az élek ebben a besorolásban azért nem alkotnak külön kategóriát, mert tulajdonságaik döntően a hálózati funkcióikhoz kötődnek. Ez alatt azt értjük, hogy például a vasúti pálya egy technikai létesítmény, ami teljes egészében a hálózaton betöltött szerepét szolgálja (míg ugyanennek a hálózatnak a csomópontja funkcionális értelemben nem kizárólag egy vasút-technológiai elem, a pályaudvar ugyanis az azt körülvevő városnak is a részét képezi, interface funkciója van). A hálózat meghatározó jellemzöi a struktúra és az irányultság; fontos mértékei általában csak vektorként fejezhetök ki.

Közlekedéshálózatok esetében a hálózati megközelítés fontosságát azért kell külön is kiemelni, mert a közlekedésgazdasági elemzések nagyon gyakran elhanyagolják azt a tényezöt, hogy a közlekedési infrastruktúra nem egyszerúen egy tôketömeg, ami bekerül a gazdasági körforgásba (a termelési függvények általában a kérdésnek ezt az oldalát tudják kezelni), hanem egyrészt fontos térbeli összefüggése van annak, hogy a közlekedési pályák mit mivel kötnek össze, másrészt egyáltalán nem elhanyagolható, hogy az összekapcsolódások milyen struktúrában, milyen mintázatot képezve valósulnak meg.

Az elemzés harmadik eleme a hálózatot magában foglaló térség, régió, aggregátum. Ezt az aggregátumot tulajdonképpen a csomópontok funkciógazdag világa építi föl, nem pedig a hálózat, mely utóbbi viszont strukturálja a csomópontok közötti viszonylatokat. Az aggregátumok minősítésére általában bonyolult aggregált mutatókat képzünk, amelyek csak a gyakorlati egyszerúsítésekben kezelödnek úgy, mintha skalár mutatók lennének (pl. GDP).

A hálózatok hatáselemeinek fenti kategorizálása közvetlen tanulságokkal szolgál az eredményesség vagy a versenyképesség értelmezéséhez is. Érdemes ugyanis megkülönböztetnünk egymástól a csomópontok eredményességét (ami a csomópontoknak korábbi önmagukhoz és egymáshoz képest kialakított pozícióját is érinti), valamint a csomópontok összessége által alkotott térség eredményességét. 
Policentrikus városhálózat esetében a csomópontokat értelemszerủen a városok jelentik, a hálózatot a közöttük létrejövő kapcsolatok strukturálják, a harmadik elemet pedig az egyes városokat körülvevỏ (a várost is magában foglaló) térség (városkörzet, kistérség) képezi.

A valódi cél nyilvánvalóan az kell legyen, hogy az aggregátum, a térség egésze legyen életképes, prosperáló, versenyképes, fenntartható stb. Ezt a célt kell szolgálnia mindkét másik összetevönek, tehát a hálózatnak is és a hálózat csomópontjainak is (amelyek esetünkben a városok). Világos, hogy az is fontos, hogy a város maga is életképes, prosperáló stb. legyen - de a városhálózat kontextusában szemlélve ez nem elég, itt éppen azt vizsgáljuk, hogy a hálózat egésze miként müködhet eredményesen. A policentrikus városhálózat-fejlesztés eredményességét nem az minösiti, hogy egyes városokat sikerül-e megfelelóen fejleszteni, hanem az, hogy a (városokat is magában foglaló) térség egésze számára mit képes e struktúra nyújtani.

Ha most külön is figyelembe vesszük a közlekedést, mint fizikai értelemben is kiépített kapcsolati funkciót, akkor azt mondhatjuk, hogy a (közlekedési) hálózat funkciója az eredményességgel kapcsolatban az, hogy a csomópontok világát, és az ebböl felépülö térség egészét segitse eredményessé válni. Az ebben való sikeresség tekinthető a hálózati működés eredményének, melynek az eléréséhez természetesen különböző hálózati konfigurációk és minöségek, ezekhez különböző költségszintek tartozhatnak.

A belső struktúra mintázata meghatározó abban, hogy mennyire válik életképessé egy adott térség

Az 1. ábra centripetális, befelé húzó rendszernek nevezi a hierarchikus, egyközpontú hálózatokat, és szembeállítja ezzel a nyitott rácsszerkezet centrifugális struktúráját. A hálózatokkal foglalkozó irodalom útbaigazítása szerint a fentebb jellemzett hátrányos tulajdonságok feloldása érdekében arra van szükség, hogy az egyes elemi pontok egyutas kényszerkapcsolata helyett választási lehetöséget kináló sokirányú kapcsolati hálók alakuljanak ki. A sokirányú kapcsolatok spontán kialakulásának azonban az egyik leküzdendő akadálya maga a korábbi működésmódot tükrözö, meglévö hálózati struktúra, továbbá az ennek magasabb csomópontjaiban kialakult kulcspozíciók ${ }^{2}$ és e relatív előnyök védelmében létrejövö ellenállás. Pontosan ennek jegyében fontos határozottan megkülönböztetni egymástól a sokirányú kapcsolatok csomópontjaiból felépülö policentrikus hálózatokat - a monocentrikus struktúrában kulcspozicióban lévö közbenső szubcentrumok pozició-növekedésére irányuló törekvéseitöl. 
Fleischer Tamás : A közlekedés szerepe a policentrikus városhálózat fejlesztésében.

Tér és Társadalom 23. évf. 2009/1. 19-42. p.

\section{1. ÁBRA}

Centripetális és centrifugális hálózatok megkülönböztetése (The Distinction of Centripetal and Centrifugal Networks)

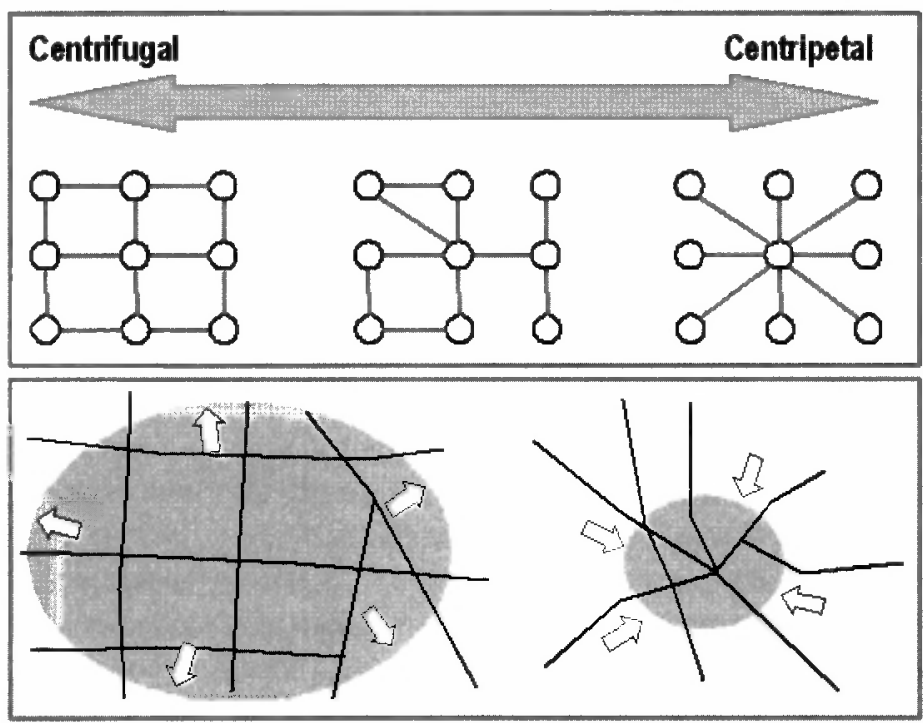

Forrás: Rodrigue (1998).

A policentrikus elven felépülö térség együttes teljesitménye válik fontossá és képviselhetővé, nem pedig az egyes központi funkciókat betöltö település súlya számit

Egy policentrikus hálózati elven felépülő térség belső közlekedési hálózatának az alakításakor feltétlenül a fö célok közé kell emelni olyan sokoldalú kapcsolatrendszer biztosítását, amely csökkenti az egyes települések kiszolgáltatottságát, és lehetővé teszi alternatív helyi fejlődési forgatókönyvek megvalósulását. Természetszerủleg a sokoldalú kooperációs formák kialakulásának gazdasági, kulturális, oktatási, szabadidős stb. dimenziókban kell végbemenniük, és ehhez szolgáló eszköz az általában valamilyen szinten meglévő vagy korábban létezett fizikai (közlekedési) kapcsolat megtartása, feljavítása, megerősítése, fejlesztése, valamint e belső struktúra hálós szerkezeti folytonosságának hangsúlyozása.

A rácsos szerkezet lényege, hogy a térség különbözỏ csomópontjait a lehetôségekhez mérten hasonló feltártsági pozíció felé közeliti, azaz valamelyest csökkenti (és nem növeli) a helyzetükböl adódó különbségeket. A korábbi kényszerkapcsolatok megléte miatt erre a fajta esélykiegyenlítésre általában szükség van a térség központja és a többi település között is, ami egyenértékủ annak a ténynek a felismerésével, hogy a térség összessége számára kell optimális feltételeket teremteni a fejlödéshez, és ez nem szükségképpen azonos a korábbról megörökölt belsö viszonyok konzerválásával. A térség növekvö fontossága ekkor a hálózati együttmüködésen alapszik; az ezt képviselni akaró központnak éppen abban kell felismernie az érdekeltségét, hogy a régió egésze fejlődjön. 
Fleischer Tamás : A közlekedés szerepe a policentrikus városhálózat fejlesztésében.

Tér és Társadalom 23. évf. 2009/1. 19-42. p.

A körülményekhez történö rugalmas adaptálódást segítő hálózati kapcsolatrendszer

Amikor a térség jó belsô feltárásával a helyi választási lehetőségek növelése irányába kívánjuk elmozdítani a pozíciókat, akkor egyben egy szemléleti váltást is képviselünk. Ennek értelmében a térség jövőjének a stabilitásához nem a tervszerü, irányított központi elképzeléshez való hatékony, uniformizált betagolódást tekintjük lényegesnek (amihez a monocentrikus hierarchikus kapcsolatok épültek ki) hanem $a$ változó körülményekhez való alkalmazkodás képességét, a rugalmasságot és a helyi körülményeknek való megfelelés támogatását.

A legutóbbi évtizedben jelentös fejlődés mutatkozott a hálózatokra vonatkozó általános elméleti kutatásokban, és ennek alapján érdemes tovább árnyalni azt a képet, amit a fenti egyszerüsítő fa-struktúra versus rács-struktúra megkülönböztetés érzékeltetett. Egy újabb megközelítés, a kis-világ hálózatok elemzése (Barabási 2003; Buchanan 2003) dinamikus gráfokkal dolgozik, ahol nem csak az élek, hanem a csomópontok száma is folyamatosan változik.

Barabási (2003) skálafüggetlen hálózatoknak nevezte el azokat a hálózatokat, amelyekre nézve igaz, hogy az egyes csomópontjaiból kiinduló kapcsolatok számának eloszlása hatvảnygörbét követ. Kiderült, hogy a hatványfüggvény írja jól le a sütóélesztő fehérjéi közötti kölcsönhatások eloszlását is, az Internet kapcsolatait is (néhány kulcsfontosságú szerverhez nagyon sokan kapcsolódnak, nagyobb számban olyan szerverek következnek, amihez kevesebben és így tovább); de hasonló képet ad a weblapokra történő hivatkozások feltérképezése is. Továbbá, ilyen eloszlást mutat az Egyesült Államok légiforgalmi rendszere is (2. ábra), vagyis néhány nagyobb csomópont nagyon sok járatot fogad naponta, ennél több, még mindig nagy csomópont kevesebbet, és többségben vannak azok a repülöterek, ahonnan kevés járat indul. Ugyancsak a 2. ábra arra is felhívja a figyelmet, hogy az úthálózat viszont nem tekinthető skálafüggetlen hálózatnak. Ez nem is meglepő, hiszen itt egy csomópontban többnyire négy él találkozik (egyszerü kereszteződés) néha csak három ( $\mathrm{T}$ elágazás) néha négynél több, de ritkán több ötnél is (hiszen a csomópont kezelhetetlenné válna). A szövetségi úthálózat konfigurációját tehát a véletlen gráf írja jól le.

Vajon milyen törvényszerüség állhat a skálafüggetlen hálózatok kialakulása mögött, ami a fehérjék kötỏdését ugyanúgy képes szabályozni, mint az Internet hálózatát kiépító embereket? Barabási megmutatta, hogy két szabályban összefoglalható az az algoritmus, ami alapján skálafüggetlen hálózatok generálhatók. A két szabály a következő: 1) a gráf csomópontjainak a száma nem eleve adott, hanem növekszik; 2) nem véletlenszerúen jönnek létre a csomópontok közötti kapcsolódások, hanem preferenciálisan: azaz egy pontnak a további kapcsolatok kialakítására vonatkozó esélye annak arányában nő, amennyi kapcsolattal a csomópont már rendelkezik (,akinek van, annak adatik"). 
Fleischer Tamás : A közlekedés szerepe a policentrikus városhálózat fejlesztésében.

Tér és Társadalom 23. évf. 2009/1. 19-42. p.

\section{2. ÁBRA}

Véletlen és skálafüggetlen hálózatok

(Random and Scale-free Networks)

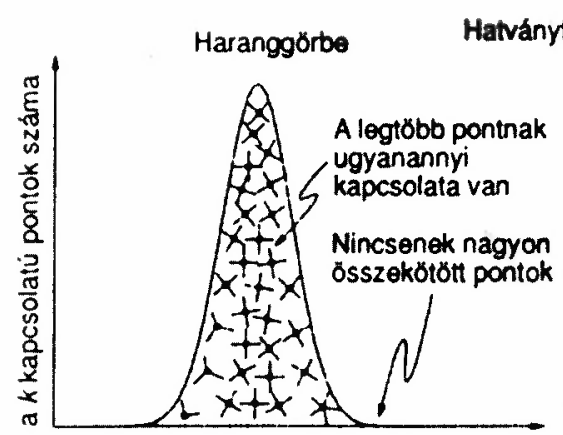

a kapcsolatok száma $(k)$

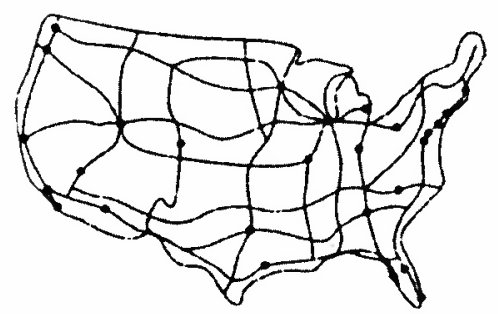

ytüggvény-eloszlás

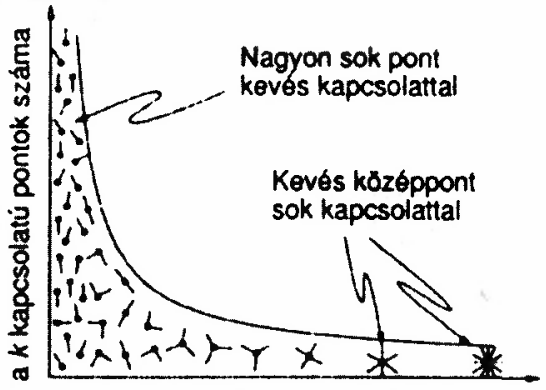

a kapcsolatok száma (k)

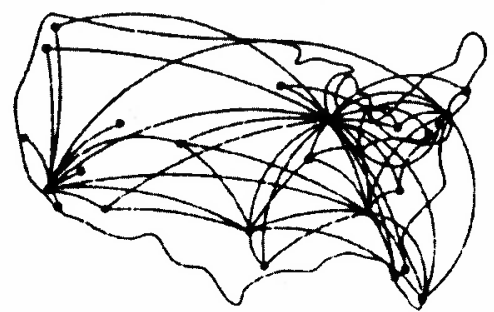

Forrás: Barabási (2003).

A kis-világhálózatok felfedezése mindenképpen egy szélesebb keretbe helyezi a hálózattal kapcsolatos korábbi ismereteket. A természetes módon fejlődő hálózatok többnyire nem rács jellegüek, hanem sajátos architektúrát alkotnak, sürün behálózott lokális gócokból állnak, ezt egészítik ki a gócokat összekapcsoló esetleges távolsági kapcsolatok. Ez a szerveződés lehetôvé teszi, hogy viszonylag kevés áttétellel ('hat kézfogással') igen távoli pontok között is kapcsolat létesülhessen, ami a közlekedésre lefordítva úgy interpretálható, hogy az algoritmus alkalmas a viszonylag kevés átszállást igénylö globális közlekedés hálózati hátterének a kialakítására.

Kevésbé bíztatóak ezeknek a hálózatoknak a kiszolgáltatottságával kapcsolatos tapasztalatok: a skálafüggetlen hálózatokban ugyanis nagyon könnyen beazonosíthatóak a legsebezhetőbb gócpontok, amelyek kiiktatása a hálózat egészének müködésképtelenségéhez vezet. Vannak azonban igen friss kutatások, amelyek olyan struktúrát keresnek, amelyik kevésbé kitett a direkt támadásnak, mint a skálamentes hálózatok, és ebből a szempontból közelít a rács-szerveződés felé.

Léteznek spontán folyamatok is, amelyek éppen hasonló irányba mutatnak (Audestad 2007). Fizikai (azaz nem virtuális) hálózatok esetében a legfrekventáltabb csomópontokhoz való csatlakozás csak egy darabig hordoz előnyöket, egy idő után éppen a csatlakozások nagy száma kezelhetetlenné válik (a repülőtér nem tudja fogadni a gépeket, az utasok nehezen igazodnak el a sok átszállási lehetőség között, a 
Fleischer Tamás : A közlekedés szerepe a policentrikus városhálózat fejlesztésében.

Tér és Társadalom 23. évf. 2009/1. 19-42. p.

„csomópont” maga is óriási méretü hálózattá dagad, az időveszteségek felemésztik a korábbi elönyöket). Ebben a tartományban a hub-méret spontán módon is korlátossá válik, és egy meglévó másik csomópontnak kell besegítenie a feladatok átvállalásával. Ez pedig éppen a policentrikus eloszlás felé közelíti a hálózat fejlödését, hiszen ebben az esetben nem hierarchia kiépüléséröl, hanem horizontális funkciómegosztásról van szó.

Bár még nem mérhetö fel teljes spektrumában, hogy a kis-világ hálózatok megismerése milyen többletet jelenthet a policentrikus városhálózatok fejlesztése vonatkozásában, úgy tủnik, hogy elsősorban a sok szállal, erős kapcsolatokkal összefonódott kisebb lokális gócok belső szerkezetét jellemezheti a policentrikus funkciómegosztás, miközben egy ilyen térségi településhalmaz összességét viszonylag kevesebb távoli kapcsolat köti össze más halmazokkal. Ma még a fejlesztésekben egy ennek ellentmondó törekvést tapasztalhatunk, amennyiben a kiépítendö kapcsolatok közül rendre a távolsági (és hierarchikus) kapcsolatok élveznek prioritást, és elhanyagoljuk a lokális térségi kapcsolatok erösítését. Ebben a vonatkozásban önmagában a rács-struktúrájú távolsági kapcsolatok kiépítésére való áttérés sem jelentene elegendỏ elörelépést, mindaddig, amíg az nem párosul a helyi, kistérségi kapcsolatok fejlesztésének az elôtérbe hozásával.

Ugyanakkor a lokális kapcsolatok elötérbe kerülésének fontosságát nem csak formális hálózati megfontolások, hanem más tapasztalatok is indokolják.

\section{Elérhetóség, a különbözö funkciók elérhetöségének biztositása}

Hagyományosan a térségi kapcsolatrendszerek elsősorban a központ jó elérhetöségére épültek. A közlekedés feladatainak végiggondolása során rá kell ébredni arra, hogy tulajdonképpen soha nem a központ elérésére, hanem bizonyos ott nyújtott funkciók, szolgáltatások elérésére van valójában szükségünk. Ezeket a szolgáltatásokat vagy akkor tudjuk jól elérni, ha könnyen odajutunk hozzájuk, vagy akkor, ha azok eleve a közelünkben vannak. Ahogy arra Hanson és Genevie (2004) rámutat, ez a meggondolás éppen ahhoz a két fogalomhoz vezet bennünket, amelyek kulcsszerepet játszanak abban, hogy helyesen értsük a közlekedés mibenlétét: nevezetesen az elérhetöséghez és a mobilitáshoz.

Az elérhetöség meghatározásuk szerint egy bizonyos távolságon vagy utazási idölimiten belül rendelkezésre álló lehetőségek mennyiségére (számára) vonatkozik - e lehetőségeket nevezik tevékenységi helyszíneknek (activity sites) is. A mobilitás arra a képességre vonatkozik, amivel mozogni tudunk a különböző tevékenységi helyszínek (pl. a lakás és a bolt) között. Ahogy a tevékenységi helyszínek között a távolságok nőnek ( $p l$. az alacsonyabb települési beépitési sürüség miatt vagy a korábbi szolgáltatás [postahivatal, iskola, kórház] megszüntetése okán), az elérhetöség egyre jobban függni kezd a mobilitástól, azaz attól, hogy rendelkezésünkre áll-e tömegközlekedés vagy éppen személygépkocsi ahhoz, hogy odajussunk a kívánt szolgáltatásokhoz. 
Fleischer Tamás : A közlekedés szerepe a policentrikus városhálózat fejlesztésében.

Tér és Társadalom 23. évf. 2009/1. 19-42. p.

TÉT XXIII. évf. 2009 - 1

A közlekedés szerepe a $\ldots$

29

Sajnálatos módon a hazai közlekedési dokumentumok (így a Magyar Közlekedéspolitika 2003-2010 vagy az Új Magyarország Fejlesztési Terv, ill. annak Közlekedési Operatív Programja is) kizárólag ezen az utóbbi szinten értelmezi az elérhetóséget, azaz adott célpontok mobilitás segítségével történó elérhetóségét értve alatta. Ez a fentiek értelmében eleve hibás, és mellözi a kérdéskör eredeti térségfejlesztési, városfejlesztési aspektusát, a tevékenységi helyszínek sürüségének és kiosztásának a kérdéskörét.

Ráadásul az egész elérhetőségi kérdéskör éppen azért került a közlekedéstervezés fókuszába, hogy felváltsa az egyoldalúan közlekedési kínálati szempontokkal számoló, mobilitáscentrikus, hagyományos tervezöi megközelítést. Analógiát keresve, az energiagazdálkodásban például már korábban világossá vált, hogy a fogyasztónak valójában nem energiára ( $\mathrm{kWh}$-ra) van szüksége, hanem bizonyos szolgáltatásokra (hö, fény stb.), amihez csak eszközül szolgál az energia. Egyáltalán nem feltétlenül a több energiához való hozzájutás a kedvező, hanem éppen ellenkezőleg az, ha ugyanazt vagy még jobb szolgáltatást éppen hogy kevesebb energia felhasználásával el lehet érni. Ugyanez érvényes a közlekedésre is: egyáltalán nem igaz, hogy minden esetben a közlekedési kínálat növelése vezetne a kedvezőbb körülményekhez; legalább ugyanolyan kedvezö lehet az is, ha a kőzlekedés segítségével elérni kívánt szolgáltatásokhoz rövidebb tóvolságon belül hozzá lehet jutni, és ezért kevesebb kőzlekedésre van szükség.

Míg az energiagazdálkodásnál könnyen megfogalmazhatóak bizonyos közvetlen keresleti elemek, amit az energia révén elóállítunk (az említett fény, fütés, vagy éppen hútés stb.) addig a közlekedés esetében ez nem látszik ennyire magától értető́dőnek. A boltba akarunk eljutni vagy a munkahelyünkre, esetleg az iskolába: de mégsem a kereskedelem vagy az oktatás az a szolgáltatás, amit a közlekedés közvetlenül felkínál nekünk, hanem a mindegyik mellé odarendelhetỏ másik szó: $a z$ eljutás. Pontosan ezért került elő az elérhetöség, mint a közlekedés keresleti oldalán értékelhető közvetlen cél, mint a kőzlekedés felhasználója számára valójában fontos szempont. Így a fentebb jelzett hazai tendencia, amelyik visszacsempészi a mobilitást az elérhetőség értelmezésébe nem egyszerüen hibás, hanem kifejezetten ellentétes a fogalom valódi funkciójával, hiszen a közlekedési kinálat növelésének indokolására használja éppen azt a fogalmat, amit a kőzlekedés keresleti oldalon történö menedzselésének a megragadhatósága érdekében vezettek be.

Azt viszont világosan látni kell, hogy ha továbbra is ellátási viszonyokban gondolkozunk, még ha az elérhetőséget a fenti értelemben használjuk (azaz a tevékenységi célhelyek eloszlását és sürüségét értékeljük vele), akkor is a dekoncentráló fejlesztés ebben a vonatkozásban közvetlenebb javulást ígérne, mint a policentrikus fejlesztés. Ha van harminc település, amely egyetlen központban jut hozzá a (nem helyi) szolgáltatásokhoz, akkor jelentósen javul a szolgáltatások elérhetősége, ha azok egy részéhez ezentúl nem csak az egyetlen központban, hanem pl. öt alközpontban is hozzá lehet jutni. Ehhez képest az elérhetőségben kevés előnyt ígér (sőt az akár romolhat is), ha szigorúan horizontális funkció-megosztással ezentúl is min- 
den szolgáltatást egyetlen helyen lehet elérni, de ez a hely most már nemcsak a korábbi központ lehet, hanem öt további település valamelyike is. Ha hozzátesszük, hogy a müködőképesség érdekében utóbbi esetben arra is szükség van, hogy a hat policentrum mindegyike jól elérhető legyen a harminc település mindegyikéröl, akkor a policentrikus fejlesztés kifejezetten hátrányosnak tünik. Visszajutunk oda, hogy ellátási szervezetként valóban a szigorú fa-struktúra a hatékony.

De vajon igaz-e az a kiindulás, hogy a településcsoport életképességét éppen egy hatékony ellátási struktúra mentén kellene értelmezni? Mélyreható szemléletváltásra pontosan ebben a vonatkozásban van szïkség, hogy t.i. belássuk, az ellátási modell egyfelöl külső források meglétét feltételezi, másrészt kifejezetten e források zérus öszszegü játszma keretében történö elosztását tekinti feladatának. Policentrikus városhálózatra nem azért van szükség, mert az tudná hatékonyabban kiszolgálni az ellátási modellt, hanem azért, mert a belsó eröforrások hasznositásához, a térségi endogén fejlödés elömozditásához a térségben lévö települések sokoldalú hálózatosodására van szükség, és ennek a fejlödésnek a bázisa a policentrikus városhálózat. A különbség megértéséhez az alábbi alpontban felidézzük a hálózatokkal foglalkozó elméleti irodalomból a hálózatok értékére vonatkozó megfontolásokat.

\section{Az elérhetöség és a térségi viszonyok együttes figyelembevétele}

\section{A hálózatok értéke: aggregált és felhasználói elönyök}

Ahhoz, hogy belássuk, miben jelentkezik a policentrikus hálózatok előnye, célszerü megismerkedni a hálózati hatásokra és a hálózatok értékére vonatkozó meggondolásokkal. Swann (2002) tanulmánya eredetileg a hálózat mérete és a hasznossága közötti összefüggést tárgyalja, mi azonban elsősorban azokra a tanulságokra vagyunk kíváncsiak, amelyek a kapcsolatrendszer mintázata és a hálózat értéke közötti öszszefüggések megállapítását teszik lehetővé.

Egyfelöl, amikor egy hálózatot értékelünk, meg kell különböztetni, hogy a hálózat aggregált értékéröl beszélünk (valamennyi felhasználó összes előnyéről) vagy pedig egyetlen egyéni felhasználó előnyéról. Másfelöl különböző jellegü hálózatokról beszélhetünk. A Swann (2003) által áttekintett irodalom három hálózati típust különböztet meg:

Az első a müsorszóró hálózat, ahol egy állomáshoz sok hallgató tartozik. Az ilyen hálózat aggregált értékét a Sarnoff-törvény írja le, eszerint ez az érték arányos a hallgatóság méretével, míg az egyes felhasználók számára a hálózat közvetlen értéke konstans, nem függ a többiek számosságától.

A második típust a kétirányú kommunikációt megvalósító hálózatok képezik. A Metcalfe-törvény szerint ilyenkor a hálózat aggregált értéke a felhasználók számának a négyzetével arányosan nő. [Az $n$ felhasználó mindegyike ( $n-1)$ másikkal képes kapcsolatba kerülni, ami $n(n-1) / 2$ kapcsolatot hoz létre.] Ugyanezért az egyes felhasználó számára a potenciális hasznosság a hálózat méretével lineárisan nő. 
Fleischer Tamás : A közlekedés szerepe a policentrikus városhálózat fejlesztésében.

Tér és Társadalom 23. évf. 2009/1. 19-42. p.

A hálózatok harmadik típusát a csoport-formáló hálózatok jelentik, ahol a hálózat hasznaként különböző közösségek alakíthatók ki. Az ilyen hálózat értékét a Reedtörvény írja le, eszerint a hálózat aggregált értéke arányos a felhasználókból kialakítható csoportok számával, vagyis $2^{n}$-nel (kettő n-edik hatványával), miközben az egyes felhasználó ebből $2^{\text {n-1 }}$ különböző csoporthoz tud tartozni, számára ezzel arányos tehát a hálózat hasznossága.

A három törvény tulajdonképpen a különböző hálózatok értékének a lehetséges felső határára ad nagyságrendi becslést. A realitást jobban figyelembe vevő következtetések arra mutatnak, hogy a valóságban ennél kevesebb az egyes felhasználó számára a hálózat effektív értéke, hiszen csak azoknak a kapcsolatoknak van számára tényleges értéke, amelyeket legalább potenciálisan valaha igénybe vehet.

Amikor egy településcsoportot vizsgálunk, akkor a köztük kiépült kapcsolatok mintázata alapján éppen arra vonatkozóan vonhatunk le következtetéseket, hogy a potenciális kapcsolatok közül azok milyen aránya jöhet ténylegesen létre.

Bár elvileg egy monocentrikus, fa-struktúrájú hálózatban is mindenki mindenkivel össze van kötve (a központon keresztül), a nem-vertikális irányú tényleges közlekedési kapcsolatokat az ilyen mintázat nagyon megneheziti, a rendszeres horizontális kapcsolatokat tulajdonképpen blokkolja. Bár kétirányú kapcsolatokról van szó, a hálózat kapcsolati értéke a gyakorlatban alig enged meg többet, mint a müsorszóró típusú hálózat. $\mathrm{Ha}$ a decentrumok egymással is összekapcsolódnak, akkor létrejön a sugaras-gyürüs hálózat. Ezzel kapcsolatban nagyon sok illúzió él a közlekedés- és a területi tervezőkben. E hálózat valóban jelentős kapcsolat-javulást hoz, hiszen közvetlen horizontális kapcsolatok is megjelennek benne; ugyanakkor rá kell mutatni arra, hogy a sugaras-gyürüs hálózat továbbra is egyközpontú struktúra marad.

Az Országos Területfejlesztési Koncepció regionális fejlesztési pólusokat és tengelyeket feltüntetó ábrája egy kifejezetten monocentrikus, sugaras-gyürüs rendszert vázol fel (3. ábra), ráadásul a sugaras jelleget még külön ki is emeli a vonalak megvastagítása ${ }^{3}$. Mindenesetre az OTK ábrája inkább egy egyközpontú, hierarchikus, dekoncentráló jellegü fejlesztési elképzelést érzékeltet, mintsem az itt tárgyalt értelemben vett policentrikus koncepciót.

Policentrikus hálózati fejlesztéssel azt lehet elérni, hogy a településhálózati kapcsolatokkal ki lehessen használni a csoport-formáló hálózatokban rejlö adottságokat - azaz, hogy ne csupán a kétoldalú, de a többoldalú kapcsolatok, koalíciók is nagy változatossággal létrejöhessenek. Fentebb láttuk, hogy az ilyen kapcsolatok képesek jelentősen növelni a hálózatok értékét, azaz azt a többletet, amivel a kapcsolatrendszer tud hozzájárulni az egyes településekben rejlő potenciálok hasznosításához. Másfelöl értelmezni tudjuk, hogy a különböző társulások, koalíciók lehetősége valóban előnyös lehet ahhoz, hogy egy település a saját adottságait különböző kombinációkban, együttmüködésekben, hálózatokban legyen képes felajánlani, értékesíteni, megnövelve ezzel saját forrásai felhasználhatóságának esélyét. 
Fleischer Tamás : A közlekedés szerepe a policentrikus városhálózat fejlesztésében.

Tér és Társadalom 23. évf. 2009/1. 19-42. p.

32 Fleischer Tamás

TÉT XXIII. évf. 2009 - 1

\section{3. ÁBRA}

Az Országos Területfejlesztési Koncepció regionális fejlesztési pólusokat és tengelyeket feltüntető ábrája

(Figure with Regional Development Poles and Axes from the National Regional Development Concept)

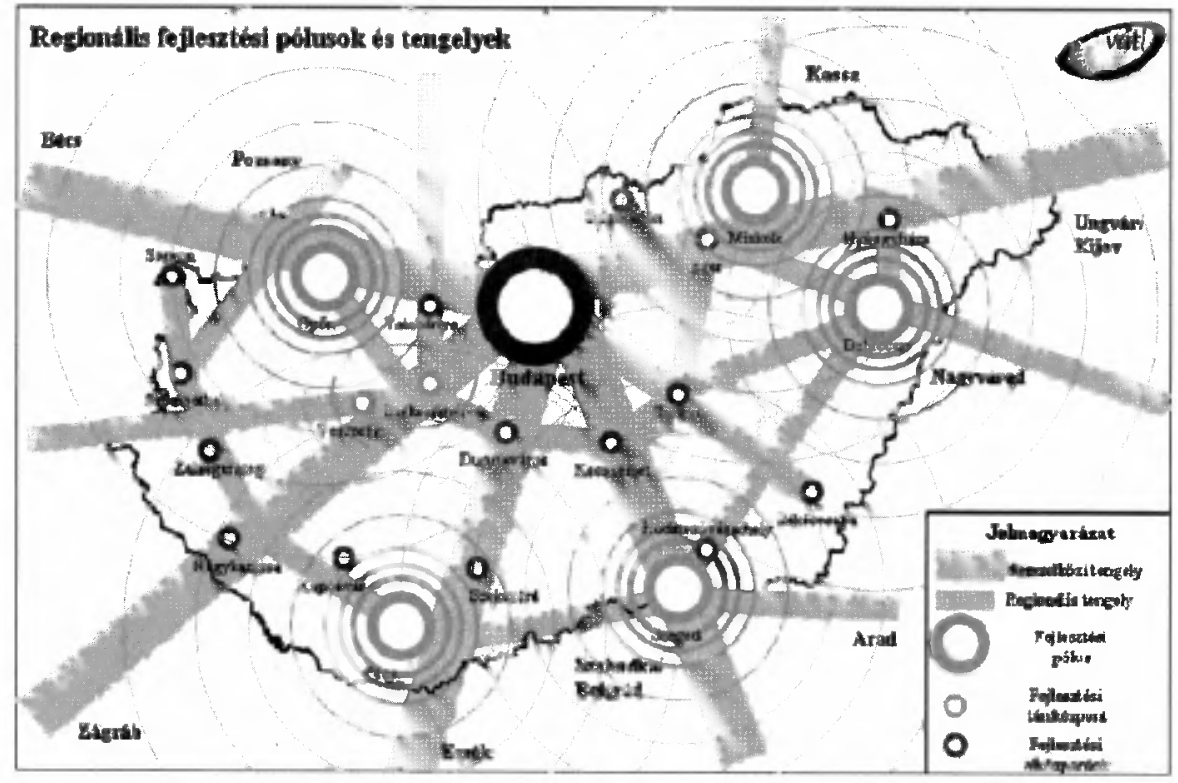

Forrás: OTK (2005).

A hálózatok térbeli hatásai: belsö és külsó kapcsolatok szerepe

Az egyes térségek fejlesztéséhez az adott térség meglévő adottságait kell tudni kombinálni külsö forrásokkal. Ha egy térség semmiféle sajátos kínálattal nem rendelkezik, akkor nem sok érv szólhat amellett, hogy bárhová letelepíthetö külső erőforrásokat miért éppen oda vigyenek. Külön-külön máshol is megtalálható adottságok értékét az növelheti fel helyi specialitássá, ha a térségen belül rendelkezésre álló lehetöségek minél nagyobb mértékben kombinálhatóak. Ezáltal a belsó kapcsolatrendszer kiterjedtsége és erössége maga is erőforrássá, versenyképességi tényezövé válik. Az ezt szolgáló belsỏ közlekedési kapcsolatok tehát ezért válnak alapvetö fejlesztési tényezövé, mint a belsö térségi struktúra épitöelemei.

A közlekedés elsődleges feladata tehát, hogy a térség belső feltáró hálózataként képes legyen megalapozni egy jól müködő, és rugalmasságot, megbízhatóságot is nyújtó kapcsolatrendszert. A policentrikus városhálózatot alulról építỏ elemi szint a policentrikus kistérség. Ez nem azt jelenti, hogy a térségen belül megszünne a különbség a kis és nagy települések között, hanem azt, hogy a kapcsolatok nem kizárólag e különbség mentén alakulnak, és ezáltal a kisebb települések sem válnak egy- 
Fleischer Tamás : A közlekedés szerepe a policentrikus városhálózat fejlesztésében.

Tér és Társadalom 23. évf. 2009/1. 19-42. p.

TÉT XXIII. évf. 2009 a 1

A közlekedés szerepe a ...

33

funkciós perifériákká. A belső kapcsolatrendszer felépit és tartósít egy belső struktúrát. A belső struktúra nélküli térségek teljesen kiszolgáltatottak a külső hatásoknak.

A belső feltárást biztosító struktúra mellett természetesen a térségnek szüksége van a külső kapcsolatok pályảira is. Míg ma jellemzően (ország, megye, kistérség léptékben is) a külső kapcsolatokra irányuló fejlesztési elképzelések mellett háttérbe szorul a belső struktúra fontossága, addig a fentiekben azt kívántuk aláhúzni, hogy a térségek saját belső kapcsolatrendszerének alapvetö szerepe van abban is, hogy a külső kapcsolatok a térség számára hasznos elemként múködhessenek.

Egy részletesebb tárgyalásban a térségi feltárás fontosságának kiemelése mellett elemezni kellene a térség megközelitését (kívülröl történő elérését), a térség átszelését és a térség elkerïlését is. Ezzel kapcsolatban korábbi munkánkra utalunk (Fleischer 2001), itt csak az általában elhanyagolt viszonylatra, azaz a többrétegú közlekedési rendszer belső feltárást ellátó hálózataira kívántuk ráirányítani a figyelmet, mint olyan elemre, ami nélkül a policentrikus városhálózat nem érthetö meg és nem müködtethetö.

\section{A policentrikus hálózatok és a biztonsági megfontolások}

Statikus körülményekre, vagy egy elképzelt, optimális mủködéshez viszonylag könnyü hatékony hálózati megoldást és takarékos kapacitásokat hozzárendelni. A mai jövő-szemléletünk nem abban különbözik a korábbiaktól, hogy most pontosabban tudnánk kiszámolni ezeket az optimumokat, hanem abban, hogy tisztában vagyunk azzal, hogy a hosszú távra tervezett létesítményeinknek olyan körülmények között kell helytállniuk, amelyeket ma nem tudunk meghatározni, és amely körülményeket ráadásul folyamatos változás fog jellemezni. Ilyen körülmények között az egy adott müködésmódra kalkulált takarékos és olcsó megoldásokkal szemben felértékelődik a megbizható és a változásokhoz rugalmasan alkalmazkodni képes megoldások fontossága. Térségi vagy makrogazdasági vonatkozásban a versenyképesség is ebben az összefüggésben, azaz 'változó körülmények között is tartós helytállásra képes' jelentésben értelmezendő.

A közlekedési kapcsolatok megbízhatósága kapcsán érdemes megkülönböztetni egymástól az elvárások kétféle léptékét: a müködés szintjét és a hálózat életciklusának a szintjét. A müködés szintjén az ellátás biztonságát olyan hálózatok képesek nagyobb mértékben szavatolni, amelyek egyrészt képesek váratlan terhelések (forgalmak) lebonyolítására, vagy legalábbis az esetleges helyi fennakadás nem okozza a teljes hálózati múködés összeomlását; másrészt egy-egy szakasz átmeneti hibája, kiesése ugyancsak kevéssé érinti a hálózat egészének a teljesítőképességét. Ezek a kívánalmak két követelményt írnak elő a hálózattal szemben: kapacitási tartalékok meglétét és alternatív útvonalak meglétét. Mind a két követelmény hagyományos értelemben redundanciát jelent, és szemben áll valamiféle rövid távú hatékonysági meggondolással. Ugyanakkor ezek a követelmények egybeesnek a policentrikus hálózattól megkívánt elvárásokkal, a nem-hierarchikus felépítéssel és a monocentrális és monofunkciós kapcsolatok meghaladásával; a sebezhetőséget fokozó koncentrációk kerülésével. 
Fleischer Tamás : A közlekedés szerepe a policentrikus városhálózat fejlesztésében.

Tér és Társadalom 23. évf. 2009/1. 19-42. p.

$34 \quad$ Fleischer Tamás

TÉT XXIII. évf. 2009

A hálózat élettartamának az időléptékét tekintve a hálózaton belül az egyes csomópontok jelentősége megváltozhat, más-más települések erőforrásai, illetve ezek új kombinációi válhatnak fontossá. Ilyen típusú súlypont-átrendezỏdéseknek a merev, egycélú hálózatok ellenállnak, mivel nem képesek követni a változásokat. Az alternatív ('redundáns') kapcsolatokkal rendelkező, sưrủ hálózatok viszont érzékelni képesek az igényekben bekövetkező eltolódást, lehetővé teszik az új kapcsolatok létrejöttét, megerősödését, új együttmüködések keletkezését. Ezeknek a követelményeknek is a policentrikus hálózatok képesek tehát jobban megfelelni.

\section{Meggondolások a policentrikus városhálózat célkitüzéseinek megfelelö közlekedéshálózat kialakitási elveire}

\section{A közlekedés hálózatai}

A különbözö múszaki hálózatok felépülése egyrészt technokratikus mintaként szolgált a településhálózatok ellátási hierarchiájának a kialakításához - de másfelöl a műszaki hálózatok fejlesztésében azután a tervezők nagyon készségesen próbálták követni a hierarchikus településhálózati lépcsőket, mely rendszerek így összességében egymást erősítve fejlödtek. A huszadik század elején már adottságnak volt vehető a foút- és a vasúthálózat fövároscentrikus struktúrája, és fejlesztési mozgástér e hálózatok esetében valójában csak a haránt irányú kiegészítések építésében nyílt volna (Erdốsi 2006). A vasútnál, mint tudjuk, semmiféle hálózatfejlesztésre nem került sor.

A közutak esetében a nagy lehetöséget a struktúra megváltoztatására az 1970-es évektől kezdve az autópályák építése jelenthette volna. Sajnálatos módon azonban mindmáig rendre a főtak vonalvezetését megismétlő hálózatdarabok épültek, újra erősítve a fơváros-centrikus fỏhálózat struktúráját, és elmulasztva egy interregionális rács-hálózat alapjainak a lefektetését (Fleischer 1994). A rács-hálózat alkalmat adott volna arra, hogy a régiókat összekapcsoló hálózati szint már ne a településhálózati hierarchiát mélyítse tovább, és hogy a különböző térségek egymás közötti kapcsolatait erősítő fő folyosók metszéspontjai esélyt teremtsenek az országos léptékủ centrumok megerősödéséhez.

E strukturális váltás fontosságát tervezési szinten Magyarországon a mai napig sem sikerült tudatosítani, amit jól tükröz az OTK nyomán korábban közölt 3. ábra. Megjegyzendő, hogy jóllehet a megépült pályák alapvetően meghatározzák és strukturálják a teret, legalább a monocentrikus szerkezet fennmaradásának a mentális csapdáit lehetne valamelyest enyhíteni az utak számozási rendszerének a megváltoztatásával. Erre van európai példa is: 1975-ig az európai föbb utak számozása a Londonból kiinduló egyszámjegyủ sugarak mentén történt (a Magyarországon átvezető Mosonmagyaróvár-Szeged tengely [azaz a mostani 4-es páneurópai folyosó] volt az E5-ös út). Ekkor a kontinens országai elérték, hogy a Nemzetközi Útügyi Szervezet megváltoztassa a számozási rendszert, és az akkor kijelölt kelet-nyugati 
Fleischer Tamás : A közlekedés szerepe a policentrikus városhálózat fejlesztésében.

Tér és Társadalom 23. évf. 2009/1. 19-42. p.

irányú föbb tengelyek 0-ra végződö, az észak-déli föbb tengelyek pedig 5-re végzödő kétjegyư számokat kaptak. Bár ettöl önmagában nem változtak meg a közlekedés körülményei, jó okunk van feltételezni, hogy ennek a mentális térképekre kiható változtatásnak szerepe volt abban, hogy tíz évvel később az Európai Közösség elkezdett a megfelelö irányú átlapoló közlekedési folyosókkal foglalkozni, majd eljutott a TEN hálózatokig.

Fentebb arra is rámutattunk, hogy önmagában a régióközi folyosók szintjén kiépülö közlekedési rács-hálózat csak az országos szint nagy centrumait képes helyzetbe hozni, és a policentrikus városhálózat fejlödéséhez arra is szükség van, hogy egy alulról építkező policentrikus kistérségi településhálózati fejlődés is meginduljon.

\section{Az áruszállitás érdekében létrehozott hálózati struktúrák problematikája}

A logisztikai szemléletmód változásban van az utóbbi időben, a korábbi nézetek és beidegződések felülvizsgálatra és átgondolásra szorulnak. Az áruszállítás elmúlt időszakát a tevékenységek koncentrálódása és az egyes csomópontok szolgáltatásokat nyújtó központokká, új szállítási célpontokká való felnövekedése jellemezte. A logisztikai központoknak a mára kiépült hálózata, a hub-ok rendszere azonban egy korábbi időszak szállítási megfontolásain nyugszik. Ebben a modellben ugyanis az áru fizikai jelenléte, helyben történő raktározása még elengedhetetlen volt ahhoz, hogy az áru további sorsáról dönteni lehessen.

Azok a technológiai lehetőségek, amelyek ma már lehetővé teszik a rakományok nyomon követését, egyedi azonosítását, nem csak a szállítások megbízhatóságát és kiszámíthatóságát képesek megnövelni, de azt is lehetövé teszik, hogy a különbözö árurakományok sorsáról azok fizikai összegyüjtése nélkül is közvetlenül diszponálni lehessen. Így megkérdőjelezhető, hogy indokolt-e gyüjtőközpontokba utaztatni hatalmas árukészleteket, csak azért, hogy azután onnan kerüljenek továbbküldésre.

A kérdéskör ott kapcsolódik össze a policentrikus városhálózatok problémájával, hogy a logisztikai központok kifejlődése ugyanazt a csomóponti hierarchián és méretgazdaságosságon alapuló nézetrendszert tükrözte vissza, mint ami az ellátási megfontolásokon nyugvó városhálózatok esetében érvényesült. Bár a logisztikai központok, nagyipari méreteik, zavaró hatásaik miatt kiszorultak a városokból, az egész jelenségkör, a probléma potenciális új megoldási mintázatai, illetve másfelől a policentrikus városhálózat kérdései kölcsönösen tanulságul szolgálhatnak egymás számára a lehetőségek felderítésében és megértésében. 
Fleischer Tamás : A közlekedés szerepe a policentrikus városhálózat fejlesztésében.

Tér és Társadalom 23. évf. 2009/1. 19-42. p.

36 Fleischer Tamás

TÉT XXIII. évf. 2009 - 1

A személyközlekedés hálózataira vonatkozó elképzelések

\section{A hálózatfejlesztés szintje}

A viszonylatok megtervezése rugalmasabb eszköz, mint a különböző pályák kiépítése, ezért a tömegközlekedési hálózatok kialakitása, ha nem is nagy mértékben, de némiképpen kompenzálhatja azokat a problémákat, amit a sugaras szerkezet elöidéz. Ahogy a fentebb jelzett útszámozási kérdéskör, úgy a viszonylatok kialakítása is egy kis lökést adhat a gondolkodásnak azzal, hogy a hierarchiától elszakadó kapcsolatokat is erősíteni kezd. Természetesen a lehetőségek nem nagyok, ahol a forgalom nem igazolja, ott nem tartható fenn a kapcsolat.

Az ilyen típusú új kapcsolatok bevezetésére is jobb esély van akkor, ha azt nem elkülönült közlekedési kérdésként kezeljük, hanem a települések együttmüködésével együtt. Ha egy kistérségi együttmüködés keretében, más tevékenységekben kialakuló kapcsolatokhoz társul a közvetlen közlekedési összeköttetés, nyilván nagyobb az esélye, hogy a lépések egymást erősítik. Hasonlóképpen a szinergiát erösíti, ha a térségi együttmüködés egyben közlekedési térségi szövetség formájában az együttmúködés keretei közé képes bevonni a közlekedés megszervezését.

A kistérségi szövetség szintjén azonban a hálózat-alakítás és a működtetés szintje nagyon szorosan össze kell kapcsolódjon, hiszen egyrészt nagyon rugalmasan kell tudni reagálni az igényekre, másrészt a közlekedés eszközparkja is jelentős flexibilitást kell mutasson a térségben rendelkezésre álló lehetőség irányában.

\section{A müködés szintje}

Kistérségi szinten a policentrális szerveződés nem igényli centrumok megjelölését, inkább arról van szó, hogy valamennyi érintett település kölcsönös elérhetőségét kell tudni biztosítani ahhoz, hogy az adott térség valóban szoros együttmüködésre legyen képes, és abból ne záródjanak ki egyes térrészek. Az ennek megfelelő közlekedés peremfeltételét úgy is megfogalmazhatjuk, hogy a városokat jellemző, vagy azt megközelítő kapcsolatgazdagságot kell kialakítani térségi szinten, de úgy, hogy közben nem exportálhatjuk a térségre a természetet sok tekintetben kiiktató urbánus mintázatot. Ennek a célnak a szolgálatába kell állitani a mai technológia lehetőségeit.

Látszólag az országban - a városok belsejéhez képest - nincs helyszüke, ezért indokolatlannak tủnhet a közösségi közlekedési formák erős prioritása. Ezzel szemben az utazások többségének legalább az egyik végpontja települések belső magját érinti, igen nagy részben városközponti területeket, ahol a preferencia indokolt. A kérdés tehát úgy merül fel, hogy melyek azok a területek/időszakok, ahonnan/amikor célszerủ a teljes utazást közösségi közlekedésre terelni, és melyek azok, ahol egy közbenső ponton célszerủ átváltani a közösségi közlekedésre. Az intelligens közlekedési rendszerek alkalmasak ilyen típusú összetett feladatok megoldására: erre alább általános elveket 
Fleischer Tamás : A közlekedés szerepe a policentrikus városhálózat fejlesztésében.

Tér és Társadalom 23. évf. 2009/1. 19-42. p.

mutatunk be, míg az egyes megoldások konkrét térbeli alkalmazása már a közlekedési szövetség keretében létrejövő intézményre hárul.

1) A fenti feltételeknek megfelelő kistérségi/helyi hálózat maga is kétszintü: továbbra is van egy vegyesfunkciós, gyalogos távolságokon alapuló kompakt mikrotér (a legkisebb települések, nagyobb települések esetén egy-egy megállóhely szükebb körzete, szomszédsági egység). Fontos és csak részben közlekedési feladat a legfontosabb napi szolgáltatások olyan módon való megszervezése, hogy azok e mikrotér elhagyása nélkül is elérhetök legyenek.

2) Közlekedési-logisztikai feladat is e szervezés azon térségek esetén, amelyek lakosság száma, vásárlóereje csak egy töredék boltot, gyógyszertárat, postát stb. képes eltartani, ezért egyfelöl a kistérségi, másfelöl az ágazatközi szinten való szervezés elkerülhetetlen. Esetenként eldöntendő kérdés, hogy mi szervezhető gazdaságosabban: olyan tömegközlekedés, melyben mindenki maga szervezi magának a mikrotere elhagyásával járó beszerzéseket, vagy pedig a tömegközlekedési hálózat mentesítése ezen utazások jelentős részétől, jól szervezett kistérségi kiszolgálórendszerrel. Úgy gondoljuk, hogy távlatilag az alacsony forgalmú térségekben egyre inkább fel kell oldani a személyszállitás és az áruterités merev elkülönitését, és közös logisztikai megoldásra kell törekedni egy-egy kistérségi diszpécserközpont kialakításával, amelynek fơ feladata a jelentkező térségi utazási/szállítási igények és a rendelkezésre álló jármü(vek) útvonalának folyamatos összehangolása.

3) Technikai, gazdaságossági és szervezési szempontból egyaránt mérlegelendö, vajon azon települések/településrészek esetében, amelyek legalább a nap egy részében elláthatók menetrendszerü közlekedéssel, a kisforgalmú napszakokban bevezethető-e ahhoz hasonló ellátás, mint ami egyébként a menetrendszerü tömegközlekedéssel nem ellátott, alacsonyforgalmú térségeket jellemzi.

4) A menetrendszerü helyi közlekedés tartományát is jelentős mértékben megnöveli, ha az ellátást nem országosan egységesített nagy buszokra alapozva és országos vállalat keretei között szervezik meg. A kistérségi felügyelet alá tartozó helyi közösségi közlekedés, amelynek irányítói adott esetben helyi taxi fuvarozókkal és falugondnokokkal is elszámolási kapcsolatban állnak, a jelenleginél jóval nagyobb rugalmassággal képes akár menetrendben megjelölt szolgáltatást is az igényekhez igazodó kapacitással ellátni.

Fentiek alapulvételével a térségi közlekedési szövetségek feladata, hogy az utaskiszolgálás szempontjainak elötérbe helyezésével, de a közlekedési üzemi funkciókat is segítve tájékoztató, információs, szervezési, intézményi és eseti kapcsolatot hozzanak létre a térségi kollektív közlekedés következö föbb rétegei között:

a) kistérségi vagy annál kisebb egységet kiszolgáló diszpécserszolgálat olyan térségekben, ahol a rendszeres menetrendszerü közlekedés nem rentábilis (a személyközlekedés mellett áruszállítási kapcsolatokat is megszervezve);

b) olyan térségek közösségi közlekedési ellátása, melyek a mainál rugalmasabb szervezéssel, menetrendszerú szolgáltatással még elláthatók; 
Fleischer Tamás : A közlekedés szerepe a policentrikus városhálózat fejlesztésében.

Tér és Társadalom 23. évf. 2009/1. 19-42. p.

c) a ma is müködő szolgáltatások, felhasználva az információs lehetőségeket mind az utaskapcsolatokban, tájékoztatásban, mind pedig az átszállási igények kulturált lebonyolításában;

d) a térséget kívülröl megközelítő járatok állomásaihoz, pályaudvaraihoz való kapcsolódások;

e) megállóhelyek, utastájékoztatási pontok, $P+R$ parkolóhelyek (autós és kerékpáros kiszolgálópontok).

\section{A közlekedéspolitika beágyazására vonatkozó követelmények}

Országos szinten az intézkedéseknek két szintjéről érdemes beszélni. Az egyik szintet a policentrikus városhálózat-fejlesztés konkrét térbeli elrendezéséhez kapcsolódó, konkrét közlekedési javaslatok megtétele jelenti. (Fentebb az ilyen intézkedéseket már sorravettük: elszakadás a monocentrikus hálózattervezéstől, rácsstruktúrák kialakítása, tömegközlekedési viszonylatokkal való támogatása, térségi intézményrendszer létrehozása stb.).

Másrészt viszont fel kell ismerni, hogy nem egyszerüen az a feladat, hogy a közlekedést hozzáigazitsuk a policentrikus városhálózat tervezett elképzeléseihez, hanem a két kérdéskörnek van egy közös meta-szintje. Mind a policentrikus városhálózatfejlesztés, mind az ehhez párosuló közlekedés-fejlesztés szemléletváltást is jelent a korábbi trendekhez képest, és az adott szerkezethez igazítandó közlekedési tervek helyett az eljárásnak (közhelyek következnek) egy demokratikus, participativ, rugalmas, fenntartható, méltányos stb., azaz a jelenlegi átfogó hazai és uniós trendeknek megfelelö tervezési folyamat keretébe kell belehelyeződniük. Azaz, a közlekedésnek nem kizárólag egy (policentrikus követelmények miatti) térbeli átrendezödésen kell átesnie, hanem ennek a lépésnek bele kell ágyazódnia a korszerü, fenntartható közlekedés érdekében amúgy is szükséges folyamatok sorába.

A Fenntartható Fejlődés Nemzeti Stratégia közlekedési háttértanulmánya (Fleischer 2005) a következő (a térbeli átrendeződés követelményét is magában foglaló) keresleti meggondolásokra támaszkodó elemek összehangolt alkalmazását szorgalmazta.

a) A közlekedés mennyiségének visszafogására irányuló lépések,

b) A motorizált közlekedés csökkentésére irányuló lépések,

c) A közlekedés térbeli megosztásának változtatása,

d) A közlekedés időbeli lefolyásának változtatása,

e) A közlekedés összetételének változtatása,

f) A közlekedés szennyezés kibocsátásának/forrásfelhasználásának csökkentése,

g) A közlekedés társadalmi beágyazódását segítő lépések,

h) A meglévő létesítmények megbecsülése, kiegészítése, felújítása. 
Fleischer Tamás : A közlekedés szerepe a policentrikus városhálózat fejlesztésében.

Tér és Társadalom 23. évf. 2009/1. 19-42. p.

Az egyes intézkedések külön-külön csak helyi vagy ideiglenes hatást képesek elérni: időben átrendezik az igényeket, de azok részben később megjelennek; mentesítenek egy területet, de a forgalom máshol felbukkan; csökken a fajlagos kibocsátás, de a forgalom növekedése felemészti ezt az elönyt stb. A változások kritikus tömege és a köztük kialakuló kereszthatások, egymást erösitö kumulativ lépések képesek a megváltozó folyamatokat tartósítani és idővel önerősítővé tenni, illetve másfelöl elérni azt, hogy a meglévő inerciák, korábbi beidegződések ne legyenek képesek visszarendezni a meginduló változásokat.

A felsorolt lépések másfelöl nem csupán közlekedési, hanem közlekedési és különbözö más területhez tartozó intézkedések összehangolt müködését is igénylik. Ilyenek a forgalomtechnikai, várospolitikai, jogi, gazdasági, illetve az építési, fejlesztési, fenntartási intézkedések (tehát például a közterületek barátságos berendezése, gyalogos és kerékpáros létesítmények építése, közforgalmú pályák építése, átszállóhelyek kialakítása, elkerülő utak megépítése, helyi hálózatok korszerủsítése, vasútállomások környékének átalakítása és funkcionális gazdagítása stb.). Az intézkedések kereteit intézményrendszeri átrendezödéssel kell biztosítani. A szempontok érvényre juttatásához a tanulmány az alábbi integrációk elérését szorgalmazta:

1) szakpolitikák, így a területi- (város-) politika és közlekedéspolitika integrációja,

2) térségi megközelítések, így a helyi, (mikroszintü) és a távolsági (makroszintü) megoldások együttmüködése, integrációja,

3) az egyes közlekedési módok integrációja,

4) a létesítmények finanszirozásának és a müködtetésük megfizettetésének összekapcsolása,

5) a dőntéshozatali folyamatok társadalmi integrációja,

6) az értékelés integrációja a tervezési és fejlesztési tevékenységbe (fenntarthatósági vizsgálatok).

\section{Összefoglalás és szakpolitikai javaslatok}

A tanulmány policentrikus városhálózaton sürün elhelyezkedő, de nem összenött városi településeket ért, amelyek között erös kölcsönös kapcsolatok alakulnak ki, miközben nincsenek egymással klasszikus hierarchikus viszonyban, kapcsolatuk alapja a specializálódás. Ennek alapján felvethető, hogy mennyire indokolt ezt átfogó (a teljes hazai városhálózatra érvényes) modellnek tekinteni. A tanulmány válaszként feltétlenül általános érvényünek tekinti az egyes szinteken belüli, hasonló helyzetben lévô városok közötti horizontális együttmüködések hangsúlyos voltát, fontosságát, továbbá a városokat magukban foglaló térségek összességére vonatkozó fejlesztési szempontok alapul vételét. A policentrikus városhálózat fejlesztésének az eredményességét nem az minősíti, hogy egyes városokat sikerül-e megfelelően fejleszteni, hanem az, hogy a (városokat is magában foglaló) térség egésze számára mit képes a struktúra nyújtani. A térségen belüli, választási lehetőséget kínáló, sokoldalú 
kapcsolati hálók képesek a térség számára a policentrikus struktúrát tartósítani, és a korábbi monocentrikus felépítéshez képest a változásokhoz való alkalmazkodás, az adaptivitás és a sokirányú együttmủködés feltételeit biztosítani.

A policentrikus hálózati séma a minimális kényszerkapcsolatokhoz képest alternatív, redundáns elérési lehetőségeket is lehetővé tesz, tehát látszólag 'pazarló' az egy adott feladat végrehajtására optimalizált hierarchiához képest. Fontos azonban megérteni, hogy a policentrikus városhálózatra nem azért van szükség, mert ez tudná a leghatékonyabban kiszolgálni az ellátási modellt, hanem azért, mert a belső erőforrások hasznositásához, a térségi endogén fejlödés elömozdításához, a változó körülményekhez történő alkalmazkodás képességéhez a térségben lévő települések sokoldalú kapesolatrendszerére van szükség, és ennek a fejlődésnek a bázisa a policentrikus városhálózat.

Hosszú távra tervezett létesítményeinknek ugyanis olyan körülmények között kell helytállniuk, amelyeket ma nem tudunk elöre meghatározni, és amely körülményeket ráadásul folyamatos változás fog jellemezni. Az adaptivitás képessége felértékelődik, és a térségi belső kapcsolatrendszer kiterjedtsége és erőssége maga is erőforrássá, versenyképességi tényezővé válik. Az ezt szolgáló belső közlekedési kapcsolatok tehát alapvető fejlesztési tényezők, a belső térségi struktúra építő elemei.

A tanulmány alapvető fontosságúnak tekinti, hogy a sugaras, monocentrikus jelleg helyett a közlekedési hálózatok is képesek legyenek a horizontális kapcsolatok kiszolgálására. Felhívtuk a figyelmet arra, hogy adott esetben az utak számozási rendje vagy a tömegközlekedési viszonylatok szervezése is elsỏ lépése lehet az egyes térségek mentális újra-térképezésének, a meglévö közlekedési kapcsolatok felhasználásának egy policentrikus településhálózat kiszolgálásában. A policentrikus közlekedési mintázat elősegítésére vonatkozó tanácsok mellett arra is rámutattunk, hogy a feladat nem egyszerúen az, hogy a közlekedést hozzáigazítsuk a policentrikus városhálózat tervezett elképzeléseihez, hanem a két kérdéskörnek van egy közös meta-szintje; ez pedig a fenntartható, méltányos és hosszú távon versenyképes térség formálása. Az ezt szolgáló közlekedésnek nem egyszerüen bizonyos speciális szempontokat kell kielégítenie, hanem átfogóan a fenntarthatósági kritériumokat. Az ilyen közlekedés kialakitását egy integrált fejlesztési intézményrendszerre kell bízni. Felsoroltuk a kívánatos integrációkat: a szakpolitikák integrációja, a helyi és a helyközi megoldások integrációja, az egyes közlekedési módok integrációja, a finanszírozás és a müködtetés összekapcsolása, a döntéshozatali folyamatok társadalmi integrációja, a tervezés és az értékelés integrációja.

\section{Köszönetnyilvánitás}

A szerző ezúton köszöni meg Paksy Gábornak a kézirat szövegéhez fủzött megjegyzéseit. 
Fleischer Tamás : A közlekedés szerepe a policentrikus városhálózat fejlesztésében.

Tér és Társadalom 23. évf. 2009/1. 19-42. p.

\section{Jegyzetek}

${ }^{1}$ A cikk alapjául szolgáló tanulmány a „Policentrikus városfejlesztési koncepció megalapozása” c. ÖTM megbízás fejezeteként készült. A munka témafelelőse Faragó László (MTA RKK) volt.

${ }^{2}$ Scharle Péter egy korábbi személyes kommentárjában járadékszedési pozíciónak nevezte az ilyen kulcspozíciókat.

${ }^{3}$ Az még külön nehezíti az ábra értelmezését, hogy a kiemelt 'fejlesztési tengelyek' nem a kiemelt pólusokat füzik fel, hanem a tervezett vagy meglévő autópálya-folyosókat mutatják, így a Balaton-part vagy Nagykanizsa fötengelyre esik, Debrecen nem.

\section{Irodalom}

Audestad, J.A. (2007) Internet as a Multiple Graph Structure: The Role of the Transport Layer. Information Security Technical Report. doi: 10.1016/j.istr.2007.02.001 (forthcoming).

Barabási A.L. (2003) Behálózva. A hálózatok új tudománya. Magyar Könyvklub, Budapest.

Buchanan, M. (2003) Nexus, avagy kicsi a világ. A hálózatok úttörő tudománya. Typotex, Budapest.

Erdősi F. (2006) A régiók közötti közlekedés fejlesztésének fơbb irányai. - Közlekedéstudományi Szemle. 8. 282-291. o.

Faragó L. (2006) A városokra alapozott teriletpolitika koncepcionális megalapozása. - Tér és Társadalom. 2. 83-103.o.

Fleischer T. (1994) A magyar gyorsforgalmi úthálózat kialakításának néhány kérdéséről. - Közlekedéstudományi Szemle. 1.7-24. o.

Fleischer T. (2001) Régiók, határok és hálózatok. - Tér és Társadalom. 3-4. 55-67. o.

Fleischer T. (2004) Kistérségi fejlödés, közlekedés, fenntarthatóság. - Közlekedéstudományi Szemle. 7. 242-252. o.

Fleischer T. (2005) Közlekedés és infrastruktúra. Szakterületi stratégia: a fenntartható fejlödés magyar stratégiájának megalapozásához. http://www.ffstrategia.hu/hatter/hatterll.pdf .

Fleischer T (2006) Hálózatok, hálózati szintek és a hálózat által kiszolgált szintek. Mühelytanulmányok. 74. MTA Világgazdasági Kutatóintézet, Budapest. http://www.vki.hu/mt/mh-74.pdf

Hanson, S.-Genevie, G. (eds.) (2004) The Geography of Urban Transportation. Guilford Press, New York.

OTK (2005) A Magyar Országgyủlés 97/2005.(XII.25.) OGY határozata az Országos Területfejlesztési Koncepcióról

Parr, J.B. (2003) Reinventing Regions? The Case of the Polycentric Urban Region. Department of Urban Studies, University of Glasgow. Conference Paper on the conference 'Reinventing Regions in a Global Economy' 12-15 April, Pisa, Italy. http://www.regional-studies-assoc.ac.uk/events/pisa03/parr.pdf

Provan, K.G.- Milward, H.B. (2001) Do Networks Really Work? A Framework for Evaluating PublicSector Organizational Networks. - Public Administration Review. 4. 414-423. o.

Rodrigue, J-P. (1998) Transport geography. Web Site. Bishop's University, Department of Geography. http://people.hofstra.edu/geotrans/index.html.

Swann G.M.P. (2002) The functional form of network effects. - Information Economics and Policy. 3. 417-429. o.

\section{THE ROLE OF THE TRANSPORTATION IN THE DEVELOPMEN OF A POLYCENTRIC URBAN NETWORK}

\section{TAMÁS FLEISCHER}

This study defines polycentric urban network as densely settled but not agglomerated urban settlements, having strong mutual links (horizontal co-operations) between them; while there are no hierarchical relations between these centres but the basis of their relation is rather a kind of specialisation. The success of the development of a polycentric urban 
network is not measured by the development of single settlements, but rather qualifying what the structure able to offer to the whole region (centres included). Multilateral relation networks that offer the possibility of choices are able to maintain the polycentric structure for a region assuring the conditions of adaptation to changes, and of multilateral co-operation, characteristically differently from the monocentric hierarchical structures. The polycentric network makes also possible alternative, redundant relations relative to the minimal linkages and this is seemingly abundant relative to the hierarchical networks that are optimalised to effectively fulfill predetermined tasks. But it is important to understand, that the aim of a polycentric urban network is not to provide a most effective hierarchical service model, but rather the effective use of internal resources, the promotion of an endogen development and the adaptation to changing circumstances are those aims that need the multilateral links between the settlements of a region. Our longstanding infrastructures has to face with future circumstances we are not able to foresee now, and what is more, which circumstances will keep on be changed. Through the growing importance of the ability of adaptivity the good pattern and strength of internal regional linkage system itself becomes a resource, a competitiveness factor. The task is not simply to adjust the transport to the visioned future of a polycentric urban network, but to solve the common meta-level of the planning: namely the formation of a sustainable, equitable, and long term competitive region. 